\title{
Theoretical Calculations of Group Electro negativities and Hardness: Properties in Groups Containing Ge, Sn and Pb and Contrast with NMR Values
}

\author{
${ }^{1},{ }^{2}$ Ricardo Vivas-Reyes, PhD. ${ }^{1}$ Jorge Puello, MSc, ${ }^{2},{ }^{3}$ Rosa Baldiris, PhD \\ ${ }^{1}$ Grupo de Química Cuántica y Teórica, Universidad de Cartagena, Facultad de Ciencias Naturales y Exactas, \\ Programa de Química. Campus de San Pablo. Cartagena-Colombia, Country, rvivasr@unicartagena.edu.co \\ ${ }^{2}$ Grupo de investigación CIPTEC. Facultad de Ingeniería. Programa de Ingeniería de Procesos. Fundación \\ Universitaria Tecnológico Comfenalco. Cartagena - Colombia \\ ${ }^{3}$ Grupo de Microbiología Clínica y Ambiental. Universidad de Cartagena, Facultad de Ciencias Naturales y Exactas, \\ Programa de Biología. Campus de San Pablo. Cartagena-Colombia.
}

\begin{abstract}
In this contribution DFT calculations were performed for a series of compounds of the type $M P h x L y(C F 3) z C F 3$, (where $M=P b, S n, G e ; L=C l, O A c ; x+y+z=$

3). The quantum chemical calculation of group electronegativities, hardness and softness of these compounds were carried out and these values compared with $19 F$ NMR spectroscopy data. A good correlation between NMR spectroscopy data and group electronegativities and hardness was found. All the calculations were performed using the B3PW91 functional together with the LanL2DZ basis set.

Keywords: DFT Calculations, hardness, electronegativity, NMR
\end{abstract}

Digital Object Identifier

(DOI):http://dx.doi.org/10.18687/LACCEI2016.1.1.283

ISBN: 978-0-9822896-9-3

ISSN: 2414-6390

$14^{\text {th }}$ LACCEI International Multi-Conference for Engineering, Education, and Technology: "Engineering Innovations for Global Sustainability", 20-22 July 2016, San José, Costa Rica. 


\title{
Theoretical Calculations of Group Electronegativities and Hardness: Properties in Groups Containing Ge, $\mathrm{Sn}$ and $\mathrm{Pb}$ and Contrast with NMR Values
}

\begin{abstract}
${ }^{1,2}$ Ricardo Vivas-Reyes, PhD. ${ }^{1}$ Jorge Puello, MSc, ${ }^{2,3}$ Rosa Baldiris, PhD Tecnológico Comfenalco. Cartagena - Colombia Biología. Campus de San Pablo. Cartagena-Colombia.

Abstract - In this contribution DFT calculations were performed for a series of compounds of the type $M P h x L y\left(C F_{3}\right) z C F 3$, (where $M=P b, S n, G e ; L=C l, O A c ; x+y+z=3$ ). The quantum chemical calculation of group electronegativities, hardness and softness of these compounds were carried out and these values compared with ${ }^{19} \mathrm{~F}$ NMR spectroscopy data. A good correlation between NMR spectroscopy data and group electronegativities and hardness was found. All the calculations were performed using the B3PW91 functional together with the LanL2DZ basis set.
\end{abstract}

${ }^{1}$ Grupo de Química Cuántica y Teórica, Universidad de Cartagena, Facultad de Ciencias Naturales y Exactas, Programa de Química. Campus de San Pablo. Cartagena-Colombia, Country, rvivasr@unicartagena.edu.co

${ }^{2}$ Grupo de investigación CIPTEC. Facultad de Ingeniería. Programa de Ingeniería de Procesos. Fundación Universitaria

${ }^{3}$ Grupo de Microbiología Clínica y Ambiental. Universidad de Cartagena, Facultad de Ciencias Naturales y Exactas, Programa de $N M R$

Keywords: DFT Calculations, hardness, electronegativity,

\section{INTRODUCTION}

Electronegativity is a key concept in chemistry through this concept is explaining much aspect in chemistry. In the past the concepts of group quantities such as electronegativities, hardness and softness have been studied by Geerlings and coworkers [1]. These quantities are important as tools in structural and reactivity studies in organic and inorganic chemistry. It have been found, for example, that the use of the principle of hard and soft acids and bases requires taking into account the group electronegativities of the corresponding groups [2-4] and for this reason it is important to know in this case and others if the comparative group electronegativities of organometallic groups remain unchanged isostructural molecules.

Molecules such as $\mathrm{MPhxLy}\left(\mathrm{CF}_{3}\right)_{\mathrm{z}} \mathrm{CF}_{3}$, (where $\mathrm{M}=\mathrm{Pb}, \mathrm{Sn}, \mathrm{Ge}$; $\mathrm{L}=\mathrm{Cl}, \mathrm{OAc} ; \mathrm{x}+\mathrm{y}+\mathrm{z}=3$ ) presents a good opportunity to expand our study of group electronegativities and hardness to other compounds of the 14 group and to make some comparisons between them [4]. The $\mathrm{Pb}$ atom gives some introductory results for the sixth row congeners of $\mathrm{C} .{ }^{19} \mathrm{~F}$ NMR spectroscopical data, which is abundant and widely available for these compounds, provides an excellent opportunity for comparison with the experimental results. [5].

\section{Theory and Computational Details}

Quantum Chemical calculation of group electronegativities, hardness and softness have been carried out for a number of compounds such as $\mathrm{MPhn}\left(\mathrm{CF}_{3}\right)_{4-\mathrm{n}}$, (where $\mathrm{n}$ run from 0 to 3,

Digital Object Identifier (DOI): http://dx.doi.org/10.18687/LACCEI2016.1.1.283 ISBN: 978-0-9822896-9-3

ISSN: 2414-6390

14 ${ }^{\text {th }}$ LACCEI International Multi-Conference for Engineering, Education, and Technology: "Engineering Innovations for Global Sustainability", 20-22 July 2016, San José, Costa Rica.
$\mathrm{M}=\mathrm{Ge}, \mathrm{Sn}, \mathrm{Pb}, \mathrm{L}=\mathrm{Cl}, \mathrm{OAc} ; \mathrm{x}+\mathrm{y}+\mathrm{z}=3), \mathrm{PbPhLn}\left(\mathrm{CF}_{3}\right)_{3-\mathrm{n} .} \mathrm{A}$ detailed discussion about the calculation of hardness, softness, and electronegativity can be found elsewhere [6-8], and only the relevant expressions used for the evaluation of these quantities are given below. The global hardness $(\eta)$, and softness $(\mathrm{S})$, electronegativity $(\chi)$, are calculated within DFT as follows:

$$
\eta \approx \frac{I E-E A}{2}
$$

Softness is the inverse of hardness:

$$
S=\frac{1}{2 \eta}
$$

The electronegativity is defined as:

$$
\chi \approx \frac{I E+E A}{2}
$$

where IE and EA are the vertical ionization energy and electron affinity of the system, respectively.

We use the expressions 1-3 as working equations to calculate the group electronegativity, hardness, and softness.

All geometries were optimized in the ground state by using the Gaussian 98 suite of programs [9] using the B3PW91 [10, 11] functional together with the LanL2DZ [12-14] basis set. For a group $\mathrm{G}$ (e.g. the $\mathrm{CH}_{3}$ group), the corresponding (neutral) radical was considered in the geometry the group usually adopts when being part of a molecule and not in the equilibrium geometry of the isolated radical. The $\mathrm{CH}_{3}$ radical, for example, is therefore considered in a pyramidal geometry and not in the planar geometry it adopts as an individual molecule. Within this option, standard bonds, angles and distances were used throughout this work using the standard structure given by Molden [15].

By calculating the radical ( $\mathrm{N}$ electron system), the cation $(\mathrm{N}-1$ electron system) and the anion $(\mathrm{N}+1$ electron system) energies of the group $\mathrm{G}$, all at the same geometry (c.f. the requirement 
of constant external potential $v(r)$ ), one can determine the ionization energy and electron affinity of $\mathrm{G}$ and thus the group quantities.

\section{Results and Discussion}

The electronegativities of $\mathrm{MPhxLy}\left(\mathrm{CF}_{3}\right)_{\mathrm{z}} \mathrm{CF}_{3}$ compounds are shown in Table 1. At this point we want to bring attention to the sub-series of compounds type $\mathrm{PbPh}_{n}\left(\mathrm{CF}_{3}\right)_{4-\mathrm{n}}$ (the first 3 compounds in Table 1); in this series if the phenyl group is changed by $\mathrm{CF}_{3}$, there is an increment in the electronegativity. To examine the influence of the central metal in the electronegativity of these compounds, the $\mathrm{GePh}_{3} \mathrm{CF}_{3}, \mathrm{SnPh}_{3} \mathrm{CF}_{3}$ and $\mathrm{PbPh}_{3} \mathrm{CF}_{3}$ were chosen.

complexes

\section{Comparison with experimental data.}

Several experimental measure quantities have been postulated to correlate with substituent electronegativities $[4,16]$ a great deal arises from the NMR spectroscopy data for which many experimental values are available in literature [5].

Table 1. Calculated group electronegativity $\left(\chi\right.$, in eV), hardness $\left(\eta\right.$, in eV) and softness $\left(\mathrm{S}\right.$, in $\left.10^{-2} \mathrm{eV}\right)$ for groups of the type $\mathrm{MPh}_{\mathrm{x}} \mathrm{L}_{\mathrm{y}}\left(\mathrm{CF}_{3}\right)_{\mathrm{z}} \mathrm{CF}_{3}(\mathrm{x}+\mathrm{y}+\mathrm{z}=3), \mathrm{M}=\mathrm{Pb}, \mathrm{Sn}$, Ge together with experimental ${ }^{19} \mathrm{~F}$ NMR shifts $\left(\delta{ }^{19} \mathrm{~F}\right.$, in ppm) and $\mathrm{J}(\mathrm{Pb}-\mathrm{F})$ coupling constant (in $\mathrm{Hz}$ ).

\begin{tabular}{|l|l|l|l|l|l|}
\hline Fragments & $\delta^{\mathbf{1 9}} \mathbf{F}[\mathbf{5}]$ & $\mathbf{J}(\mathbf{M}-\mathbf{F})$ & $\chi$ & $\eta$ & $\mathbf{~}$ \\
\hline $\mathrm{PbPh}_{3}$ & 37.8 & 324 & 4.63 & 2.40 & 20.92 \\
\hline $\mathrm{PbPh}_{2} \mathrm{CF}_{3}$ & 40.3 & 440 & 5.10 & 2.54 & 19.69 \\
\hline $\mathrm{PbPh}\left(\mathrm{CF}_{3}\right)_{2}$ & 41.2 & 560 & 5.60 & 2.72 & 18.32 \\
\hline $\mathrm{PbPh}_{2} \mathrm{Cl}$ & 40.2 & 301 & 5.58 & 2.53 & 19.76 \\
\hline $\mathrm{PbPh}_{2}(\mathrm{OAc})$ & 40.6 & 321 & 5.62 & 2.43 & 20.49 \\
\hline $\mathrm{PbPh}(\mathrm{OAc})_{2}$ & 40.5 & 349 & 6.25 & 2.55 & 19.61 \\
\hline $\mathrm{PbPh}(\mathrm{OAc}) \mathrm{CF}_{3}$ & 39.4 & 503 & 6.07 & 2.54 & 19.69 \\
\hline $\mathrm{SnPh}_{3}$ & 31.2 & 285 & 4.47 & 2.56 & 19.53 \\
\hline $\mathrm{SnPh}_{2} \mathrm{CF}_{3}$ & 30.1 & 427 & 4.92 & 2.70 & 18.59 \\
\hline $\mathrm{GePh}_{3}$ & 28.2 & -- & 4.29 & 2.75 & 18.18 \\
\hline
\end{tabular}

of the fragment increases according to the following Equation (5):

For the compounds with phenyl and $\mathrm{CF}_{3}$ groups acting as ligands $\left(\mathrm{MPhn}\left(\mathrm{CF}_{3}\right)_{4-\mathrm{n}}\right.$, with $\mathrm{n}$ running from 1 to 3 and $\mathrm{M}=\mathrm{Sn}$, $\mathrm{Pb}$ ) a good agreement, with a linear correlation was found between $\mathrm{J}(\mathrm{M}-\mathrm{F})$ and electronegativity (See Figure 1). The increase of the $\mathrm{s}$ character in the $\mathrm{Pb}-\mathrm{CF}_{3}$ bond as $\mathrm{CF}_{3}$ groups are substituted for phenyl groups, has as consequence that $2 \mathrm{~J}\left(\mathrm{M}-{ }^{19} \mathrm{~F}\right)$ increases from 323 to $557 \mathrm{~Hz}$ for the series $\mathrm{PbPhn}\left(\mathrm{CF}_{3}\right)_{4-\mathrm{n}}, \mathrm{SnPh}_{3}\left(\mathrm{CF}_{3}\right)$ and $\mathrm{SnPh}_{2}(\mathrm{CF} 3) 2$ [5]. The degree of this increase is followed by an increment in the electronegativity $(\chi)$ according to the following equation (4):

$$
J(M-F)=243.26 \chi-799.27 ; r^{2}=0.997
$$

For the $\mathrm{MPh}_{3} \mathrm{CF}_{3}$ compounds $(\mathrm{M}=\mathrm{Pb}, \mathrm{Sn}, \mathrm{Ge}),{ }^{19} \mathrm{~F}$ chemical shifts become slightly more shielded as the central element becomes located more toward the top of the periodic table [3], and this is well correlated (see Figure 2), with the fact that ${ }^{19} \mathrm{~F}$ chemical shifts increase when electronegativity $(\chi)$

$$
\Delta \delta=28.24 \cdot-93.52 ; r^{2}=0.955
$$

All these results suggest that a change in ${ }^{19} \mathrm{~F}$ NMR Spectroscopy data in this kind of compounds qualitatively could reflect, with a large degree of certainty, the corresponding change in group electronegativities.

For the mixed ligand species of this series $\left(\mathrm{PbPh}_{2} \mathrm{Cl}\right.$, $\mathrm{PbP}_{2}(\mathrm{OAc}), \mathrm{PbPh}(\mathrm{OAc})_{2}$ and $\left.\mathrm{PbPh}(\mathrm{OAc}) \mathrm{CF}_{3}\right)$, the relation is not that simple. The best correlation found was a dual model including electronegativity and hardness (see Figure 3); the model suggest a good correlation between these quantities $(\chi, \eta)$ and $\Delta \delta$. Figure labels should be legible, at 8-point type. 


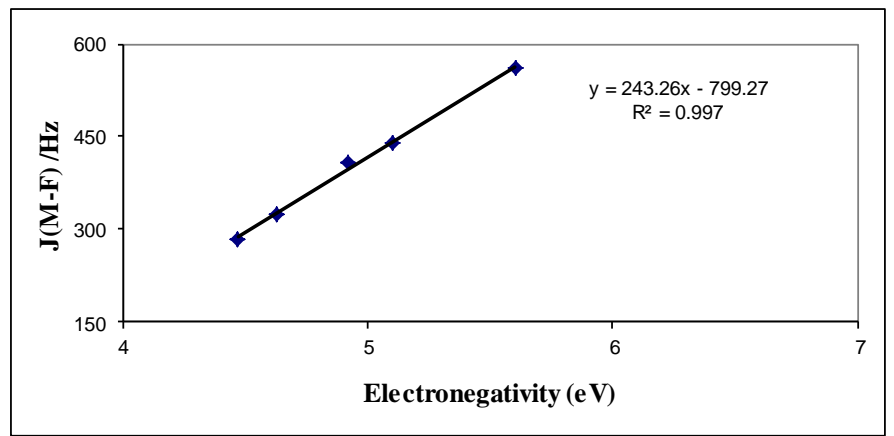

Figure 1. Experimental 2J(M-F) chemical Shifts vs. group electronegativity of $\mathrm{MPhn}\left(\mathrm{CF}_{3}\right)_{3-\mathrm{n}}(\mathrm{M}=\mathrm{Sn}, \mathrm{Pb})$ compounds.

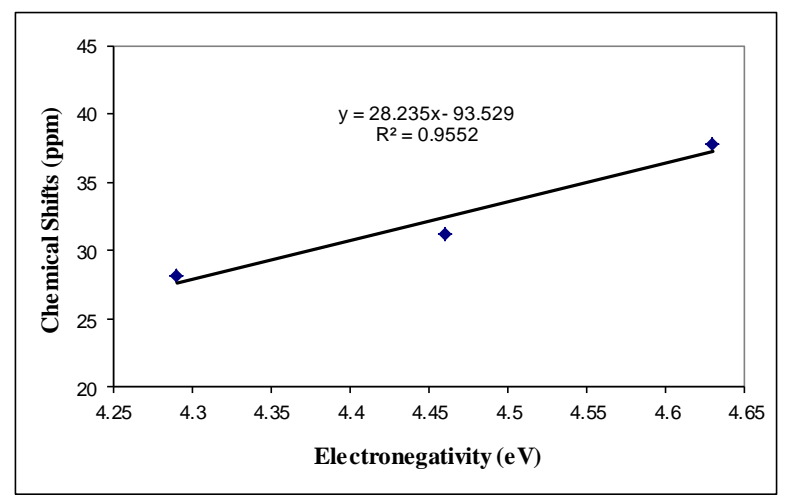

Figure 2. Experimental ${ }^{19} \mathrm{~F}$ chemical shifts of $\mathrm{MPh}_{3}\left(\mathrm{CF}_{3}\right)(\mathrm{M}=$ $\mathrm{Ge}, \mathrm{Sn}, \mathrm{Pb}$ ) vs. group electronegativity values.

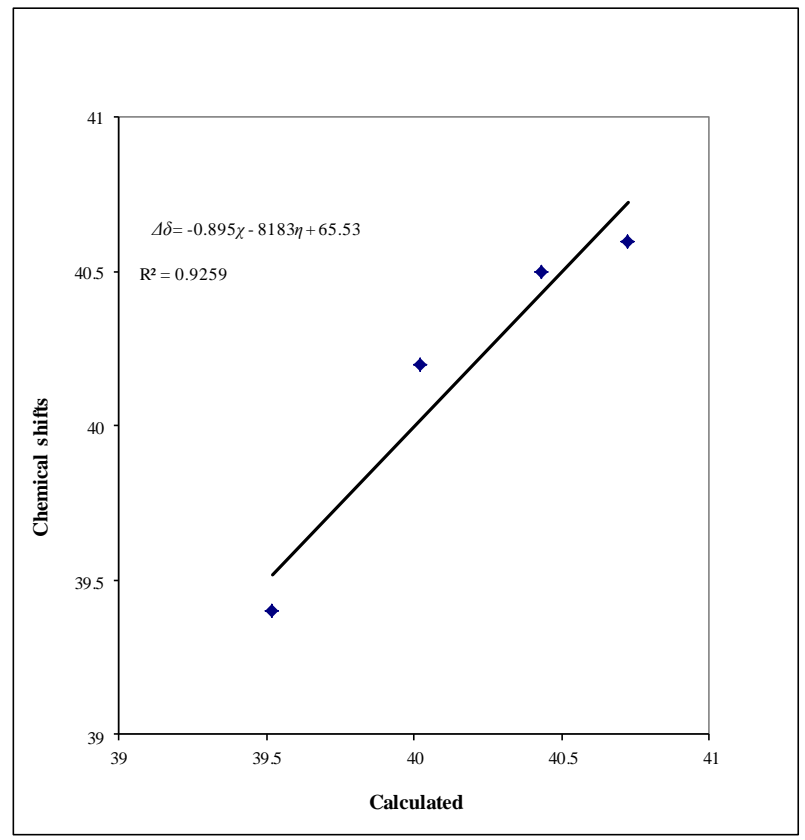

Figure 3. Experimental ${ }^{19} \mathrm{~F}$ chemical shifts vs. values obtained via dual correlation between hardness and electronegativity for $\mathrm{PbPhLn}\left(\mathrm{CF}_{3}\right)_{3-\mathrm{n}}$ and $\mathrm{PbPh}_{2} \mathrm{~L}\left(\mathrm{CF}_{3}\right)$ compounds
$\Delta \delta=-0.895 \chi-8183 \eta+65.53 ; r^{2}=0.926(6)$

\section{Conclusions}

Quantum Chemical calculations of group electronegativities and hardness (softness) were carried out for some elements of Group 14 of the Periodic Table such as $\mathrm{Ge}, \mathrm{Sn}, \mathrm{Pb}$ and some of their Containing Functional Groups. These calculations allowed noticing the regularities concerning the influence exerted by of the nature of organic and inorganic groups on electronegativities. These data could also be used for interpretation of reactivity and how this is affected for the presence of different substituents and groups in a molecule.

The comparison between the group electronegativities and experimental chemicals shifts values are acceptable and all these results suggests that a change in ${ }^{19} \mathrm{~F}$ NMR spectroscopy data in this kind of compounds qualitatively reflects a quite good degree of certainty the corresponding change in group electronegativities. For example, it was found that the group properties of molecules of the type $\mathrm{MPhxLy}\left(\mathrm{CF}_{3}\right) \mathrm{ZCF}_{3}$ are highlighted for the electronegativity and hardness of the substituent groups; in this way this kind of calculations is a valuable tool in order to interpret relevant structural information.

\section{Acknowledgements}

R.V.R. thanks the Cartagena University for financial support to his Group.

\section{References and Notes}

1. De Proft, F.; Langenaeker, W and Geerlings, P. Ab initio determination of substituent constants in a density functional theory formalism: calculation of intrinsic group electronegativity, hardness, and softness. J. Phys. Chem. 1993, 97, 1826-1831

2. Geerlings, P.; De Proft, F and Langenaeker, W. Conceptual Density Functional Theory, Chem Rev. 2003, 103, 1793-1874

3. a. For a series of papers covering various aspects of electronegativity see: in K.D. Sen and C.K. Jørgensen (Eds.), Structure and Bonding, Vol. 66, Springer Verlag, Berlin, 1987.

4.a. Vivas-Reyes, R. Arias. A. Evaluation of group electronegativities and hardness (softness) of group 14 elements and containing functional groups through density functional theory and correlation with NMR spectra data Eclectica Química, 2008, 33, 69-76. b Vivas-Reyes, R. Arias, A. Vandenbussche, J. Van Alsenoy, C. Bultinck. P. Quantum similarity of isosteres coordinate versus momentum

14 ${ }^{\text {th }}$ LACCEI International Multi-Conference for Engineering, Education, and Technology: "Engineering Innovations for 
space and influence of alignment. Journal of Molecular Structure: THEOCHEM. 2010. 943 (1), 183-188.

5. Galiotos, J.K.; Morrison. J. A. Preparation and Properties of Trifluoromethylated Aryl Derivatives of Germanium, Tin, and Lead. High-Yield Syntheses of Trifluoromethylbenzene J. Organomet. 2000, 19, 2603-2607.

6. a. Gerrlings, P.; De Proft. F. Chemical Reactivity as Described by Quantum Chemical Methods. Int. J. Mol. Sci. 2002, 3, 276-309. b. Vivas-Reyes, R. De Proft, F. Biesemans, M. Willem. Geerlings, P. A DFT Study of Tin-and Crown-Ether-Based Host Molecules Capable of Binding Anions and Cations Simultaneously. European Journal of Inorganic Chemistry, 2003 (7), 1315-1324. c. De Proft, F. Vivas-Reyes, R. Biesemans, M. Willem, R. Martin, JML. Geerlings, P. Density functional study of the complexation reaction of $\mathrm{Sn}(\mathrm{CH} 3) 3 \mathrm{X}(\mathrm{X}=\mathrm{F}, \mathrm{Cl}, \mathrm{Br}$ and $\mathrm{I})$ with halide anions. European Journal of Inorganic Chemistry 2003 (20), 3803-3810. d. Vivas-Reyes, R. Núñez-Zarur, F. Martinez, E. Electronic structure and reactivity analysis for a set of Zn-chelates with substituted 8-hydroxyquinoline ligands and their application in OLED. Organic Electronics. 2008. 9 (5), 625-634.

7. Parr R. G. and Yang, W. Density Functional Theory of Atoms and Molecules, Oxford University Press, New York, 1989.

8. Geerlings; De Proft, F.; Langenaeker, W. In Density Functional Methods and Material Science; Sprinborg, M., Ed.; John Willey: New York, Chapter 2, 1997.

9. Frisch, M. J.; Trucks, G. W.; Schlegel, H. B.; Scuseria , G. E.; Robb , M. A.; Cheeseman, J. R.; Zakrzewski, V. G.; Montgomery, J. A.; D.; Kudin, K. N.; Strain, M. S.; Farkas, O.; Tomasi, J.; Barone, V.; Cossi, M.; Cammi, R.; Mennucci, B.; Pomelli, C.; Adamo, C.; Clifford, S.; Ochterski, J.; Petersson, G. A.; Ayala, P. Y.; Cui, Q.; Morokuma, K.; Malick, D. K.; Rabuck, A. D.; Raghavachari, K.; Foresman, J. B.; Cioslowski, J.; Ortiz, J. V.; Baboul, A. G.; Stefanov, B. B.; Liu, G.; Liashenko, A.; Piskorz, P.; Komaromi, I.; Gomperts, R.; Martin, R. L.; Fox, D. J.; Keith, T.; Al-Laham, M. A.; Peng, C.Y.; Nanayakkara, A.; Gonzalez, C.; Challacombe, M.; Gill, P. M. W.; Johnson, B.; Chen, W.; Wong, M. W.; Andres, M.; Head-Gordon, M.; Replogle, E. S.; Pople, J. A. Gaussian 98; Gaussian Inc., Pittsburgh, PA, 1998.

10. a) Becke, A. D. Density functional thermochemistry. III. The role of exact exchange. J. Chem. Phys 1993, 98, 5648-52 b) Lee, C. Yang. W. Parr. R. G. Development of the ColleSalvetti correlation-energy formula into a functional of the electron density Phys. Rev. B, 1998, 37 1988, 785 c) Stephens, P.J.; Devlin, F. J.; Chabalowski, C.F.; Frisch, M.J. $\mathrm{Ab}$ Initio Calculation of Vibrational Absorption and Circular Dichroism Spectra Using Density Functional Force Fields. J. Phys. Chem. 1994, 98, 11623.

11. Perdew, J. P.; Wang, Y. Accurate and simple analytic representation of the electron-gas correlation energy. Phys. Rev. B. 1992, 45, 13244.
12. Hay, P. J and Wadt, W. R. Ab initio effective core potentials for molecular calculations. Potentials for the transition metal atoms Sc to Hg. J. Chem. Phys. 1985, 82, 270. 13. Wadt, W. R. and Hay, P. J. Ab initio effective core potentials for molecular calculations. Potentials for main group elements Na to Bi J. Chem. Phys. 1985, 82, 284.

14. P. J. Hay and W. R. Wadt, Ab initio effective core potentials for molecular calculations. Potentials for $\mathrm{K}$ to $\mathrm{Au}$ including the outermost core orbitals J. Chem. Phys. 1985, 82, 299.

15. Schaftenaar, G. and Noordock, J. H. The effect of isodensity surface sampling on ESP derived charges and the effect of adding bond centers on DMA derived charges J. Compt. Aided Mol Desig. 2000, 14, 123.

16. Vivas-Reyes, R., De Proft, F., Biesemans, M., Willem, R., Geerlings, P. DFT Calculations of 119Sn Chemical Shifts Using Gauge-Including Atomic Orbitals and Their Interpretation via Group Properties J. Phys. Chem. A. 2002, $106,2753$.

14 ${ }^{\text {th }}$ LACCEI International Multi-Conference for Engineering, Education, and Technology: "Engineering Innovations for Global Sustainability”, 20-22 July 2016, San José, Costa Rica. 